\section{Household pesticide exposure: an online survey and shelf research in the Metropolitan Region of Rio de Janeiro, Brazil}

\author{
Exposição domiciliar a pesticidas: um inquérito \\ eletrônico e pesquisa de varejo na Região \\ Metropolitana do Rio de Janeiro, Brasil
}

Exposición de los hogares a los pesticidas: una
encuesta online e investigación de campo en la
Región Metropolitana de Río de Janeiro, Brasil

\begin{abstract}
This study aimed to estimate household pesticide exposure in adult individuals in the Metropolitan Region of Rio de Janeiro, Brazil, and to verify the accessibility of these products in local and online businesses. The data were collected by an online questionnaire (1,015 responses) and a shelf survey in physical and online stores. Among the responses analyzed, 87.5\% used pesticides in the previous year, most of which against mosquitoes (64.7\%). The most common application method was aerosol spray (38.1\%), and the most frequent places of use were bedrooms (29.7\%) and living rooms (22.1\%). About 30\% of respondents reported invasion of pests, and the most common pests were ants (79.1\%) and cockroaches (40.4\%). Service area (71.6\%) and kitchen (17.5\%) were the most common storage locations. Approximately 91\% of those who lived with children aged under 18 used pesticides. The use of chemical group of pyrethroids prevailed (81.6\%), and $90.8 \%$ of the reportedly used products are class II [55.7\% (highly toxic)] or class III [35.1\% (medium toxic)]. The most significant amount of purchased products was in the pest category, followed by mosquitoes. More variety of products were available in online stores than in physical stores. The high exposure of the population to pesticides at household is a public health issue and confirms the need for studies that better assess the risks and consequences of chronic and low-dose exposure to these substances. It is essential to inform the population about the uncertainties and potential risks of indiscriminate use so that they can choose whether to use pesticides in their households.
\end{abstract}

Pesticides; Housing; Questionnaire; Internet Access
Leandro Lopes da Silva Galdiano 1

Valéria Troncoso Baltar 1

Silvia Polidoro 2

Valentina Gallo 3

\author{
Correspondence \\ L. L. S. Galdiano \\ Universidade Federal Fluminense. \\ Rua Miguel de Frias 9, Niterói, RJ 24220-900, Brasil. \\ leandrogaldiano@id.uff.br \\ 1 Universidade Federal Fluminense, Niterói, Brasil. \\ 2 Italian Institute for Genomic Medicine, Turin, Italy. \\ 3 Queen Mary University of London, London, U.K.
}




\section{Introduction}

Pesticides are chemical compounds used to kill pests, including insects, rodents, fungi, and unwanted plants (weeds). Mostly used in public health to kill disease vectors, such as mosquitoes, and in agriculture, to kill pests. Besides, pesticides are potentially toxic to other organisms, including humans, and must be used safely and disposed of properly 1 . They can be found in most environments, particularly in soil and air, drinking water and food consumed by humans and animals 2.

Human exposure to pesticides is quite common. It occurs at high levels in occupational environments (production and spraying activities in agriculture), at low levels in homes, carried mainly in clothes and shoes contaminated by garden treatment 3,4 and as residues in food. This can result in acute and delayed health effects. Several scientific studies have reported a statistical association between prolonged exposure to pesticides and harmful effects on human health, however, without sufficient strength to demonstrate causality 5,6,7,8,9,10,11. These effects would include, leukemia, lymphomas, soft tissue sarcomas, brain, bone, and stomach cancer in farmers, sprayers, and agricultural producers ${ }^{12}$. A relationship between parental exposure and childhood cancer has also been reported in human studies, as well as a role for pesticides in the occurrence of Parkinson's disease and developmental defects 13,14 .

Although most pesticides currently marketed for domestic use have evolved in their physicalchemical characteristics in order to become safer, precautions must be taken for their use, since deaths from poisoning and multiple harmful effects have already been reported after the inappropriate use of these substances 15 .

Recent studies on the use of household insecticides are scarce. The existing literature is predominantly related to the occupational use of insecticides. Considering the similarity between various agricultural and domestic insecticides, it is estimated that its widespread and indiscriminate use in urban households also cause damage or harm to human health, constituting a potential public health problem 16 . When we add the time factor to this estimated widespread and indiscriminate use, with prolonged exposure for years, the issue becomes even more serious.

The use of insecticides has become increasingly common in urban households over the years, particularly in the state of Rio de Janeiro, Brazil, with the recent epidemics of Zika virus and chikungunya virus starting in 2015, as these substances kill mosquitoes that transmit these diseases. The analysis of the annals of the Brazilian Association of Cleaning and Related Products Industries (ABIPLA) showed that the sales of home use insecticides increased from BRL 427 million in 2005 to BRL 1.3 billion in 2016. Specifically, aerosol-applied insecticide sales hiked from 17,246 units in 2005 to 101,154 units in 201517.

People in the Metropolitan Region of Rio de Janeiro is frequently using these products and experiencing greater exposure to pesticides in their households, an issue that must be investigated given the harmful potential of this exposure.

Considering the gaps identified in the literature review, the local reality and the wish to contribute to literature addressing this issue we conducted a study on the pattern of domestic insecticide in adult individuals in the Metropolitan Region of Rio de Janeiro in order to estimate the exposure to household pesticides, and to verify the accessibility of these products in local and online stores.

\section{Method}

\section{Data collection}

Three parallel surveys were conducted to verify exposure to household pesticides in adult individuals in the Metropolitan Region of Rio de Janeiro (Research Ethics Committee of the Fluminense Federal University - CAEE 89859618.3.0000.5243). 


\section{- Online questionnaire}

The data was collected with the distribution of a structured online questionnaire, as widely as possible, among people living in urban areas of the Metropolitan Region of Rio de Janeiro, with dissemination by social media and personal contacts. The instrument used was prepared by the authors, containing open-ended and closed-ended questions, and was hosted on the SurveyMonkey website (https://www.surveymonkey.com/).

Available from July 3, 2018, to August 3, 2018, this questionnaire could be accessed by a web link that was inserted in a brief message explaining the reason for the research. We invited people to participate and was publicly disclosed and shared on several social networks, such as Facebook and Instagram. A Facebook page was created, and the invitation to respond was actively promoted as an event. No incentive was paid to those who responded. The hyperlink was sent by e-mail to thousands of people through distribution lists, and via WhatsApp software app distribution lists.

By agreeing with the terms of the survey, the respondents answered up to 65 questions, 18 of which were open-ended, and the rest closed-ended, referring to the previous year. The mean response time was 5-8 minutes.

\section{- Shelf research}

The shelf survey was performed to identify which pesticides are available in supermarkets in the Metropolitan Region. In total, 19 supermarkets were visited from 18 districts and 13 different retailers, located in three municipalities in the Metropolitan Region. The choice of the surveyed municipalities in the Metropolitan Region and the district, zone or region within those municipalities was guided by the analysis of the responses to two questions from the online questionnaire that indicated their regions within those were with the highest absolute frequency of responses to the survey quiz. Within these regions, the districts selected for a visit were three most populous according to the 2010 Demographic Census from Brazilian Institute of Geography and Statistics (IBGE). We intended to bring the survey of the public closer to the public who answered the online questionnaire. The choice of supermarket retailers in the selected districts was driven by the composition between the convenience of conducting the survey (security in the region, easy access, and on-site parking) and the intention to include a more significant number of different retailers, understanding that this variation of portfolio is more comprehensively the exposure of the researched population to the range of pesticides available.

The pesticides present in each supermarket were registered with pictures or videos during the visit. Data were collected in November and December 2018 and organized in a Microsoft Excel spreadsheet (https://products.office.com/). Besides the different types of products found in each supermarket, their price, targeted use (divided into four categories, namely, mosquitoes, pests, plants, or domestic animals), route of application, and the chemical components of the formulation were also noted.

\section{- Online shelf research}

The online survey was conducted on the official website of the stores visited in the shelf survey, which made available the purchase of pesticides over the internet in February 2019. Four supermarket retailers were evaluated for price, quantity, and variety of pesticides available online to compare these requirements with the ones found on the physical store shelf. We employed both search function on the sites, with keyword-based search, and direct access, by product category. The pesticides found were recorded in an Excel spreadsheet with the product volume, prices, and route of application, in the same way that the information was recorded in the store search. The keywords used were: pesticide, insect, flea, mold, plant, ant, fly, cockroach, rat, bug, louse, moth, termite, mosquito, rat, cat, and dog. As for the "target of use", the products were coded using the same four categories used for search in the store (mosquitoes, pests, plants, or domestic animals). 


\section{Statistical data analysis}

The analyses of the qualitative variables of both surveys were expressed as frequency and percentage. The association between the use of insecticides and the fact that they interact with children aged under 18 years was analyzed using the chi-square test. A significance level of 0.05 was adopted. All data were analyzed using IBM SPSS software version 20.0 (https://www.ibm.com/).

\section{Results}

\section{Online survey}

This study on the domestic use of pesticides in the Metropolitan Region of Rio de Janeiro returned 1,095 responses, and $7.3 \%$ of respondents were excluded because they either did not live in the Metropolitan Region or were aged under 18, and did not qualify for the survey. Out of the 1,015 valid responses, we decided to analyze the responses from 927 (91.3\%) individuals residing in Niterói, Rio de Janeiro or São Gonçalo. Only seven people answered that they used products in gardens, which made the frequency of use of them minimal and we chose not to include this data.

The characteristics of the studied sample are shown in Table 1.

Most questionnaire respondents used pesticides at household in the previous year (87\%) (Table 2).

Among the respondents who reported the use of some pesticides in the previous year, the majority used them against mosquitoes (64.7\%), pests (43.2\%), in domestic animals (28.7\%) and, finally, in plants (6.4\%). The main places of use were bedroom (29.7\%), living room (22.1\%), kitchen (10.6\%), and bathroom (10.4\%). When analyzing only the use of pesticides against mosquitoes, 76\% (436) applied them in the bedroom, 56\% (324) in the living room, and 22\% (128) of all participants used them at least four times a week. The most used product was the skin repellent (52.1\%). Furthermore, out of the total valid respondents to the questionnaire, we found that $29.9 \%$ reported pest invasion in their households, the most common of which were ants (79.1\%), cockroaches (40.4\%), flies (22\%), moths (21.7\%), and termites (19.5\%); $29.9 \%$ store pesticides at home, and the service area is the most common place $(71.6 \%)$ followed by the kitchen (17.5\%); and 4.9\% reported occupational exposure.

\section{Questionnaire responses by household}

Out of the 927 respondents, most lived in Niterói (428; 46.2\%), followed by Rio de Janeiro (407; 43.9\%) and São Gonçalo (92; 9.9\%).

Table 3 shows the frequency of responses by zone, region, and district of municipalities in Rio de Janeiro and Niterói.

\section{Use of pesticides according to the place of residence}

Regarding the positive responses to the use of pesticides by municipality studied, we can observe that the most used type of pesticide was against mosquitoes (Table 4) in all municipalities.

In the responses by region in Niterói, by zone in Rio de Janeiro, and the district of São Gonçalo, the use of pesticides against mosquitoes occurred in more than $50 \%$ of respondents in all areas surveyed (Table 5).

\section{Pesticide use among those living with children under 18}

The results of the online survey show that, in the previous year, out of the 285 respondents (30.7\%) who lived with children aged under 18, 259 (90.8\%) used pesticides. Most of them used pesticides from more than one category. About $60 \%$ used products against mosquitoes, $20.7 \%$ used pest control products, $15.8 \%$ used it for domestic animals, and 3.3\% used it for plants. Only $60.3 \%$ suffered pest invasions in the previous year, suggesting that almost $40 \%$ used them for preventive purposes. 
Table 1

Characteristics of the studied sample.

\begin{tabular}{|c|c|}
\hline Characteristics & Frequency (\%) \\
\hline \multicolumn{2}{|l|}{ Gender * } \\
\hline Female & $608(65.6)$ \\
\hline Male & $300(32.4)$ \\
\hline Would rather not say & $2(0.2)$ \\
\hline \multicolumn{2}{|l|}{ Age range (years) ** } \\
\hline $18-24$ & $181(19.9)$ \\
\hline $25-34$ & $219(24.1)$ \\
\hline $35-44$ & $181(19.9)$ \\
\hline $45-54$ & $144(15.8)$ \\
\hline $55-64$ & $129(14.1)$ \\
\hline$>65$ & $56(6.2)$ \\
\hline \multicolumn{2}{|l|}{ How many people share the house * } \\
\hline 0 & $86(9.3)$ \\
\hline 1 & $262(28.3)$ \\
\hline 2 & $249(26.9)$ \\
\hline 3 & $208(22.4)$ \\
\hline 4 & $73(7.9)$ \\
\hline 5 & $18(1.9)$ \\
\hline 6 & $8(0.9)$ \\
\hline 7 & $1(0.1)$ \\
\hline 8 & $1(0.1)$ \\
\hline+9 & $4(0.4)$ \\
\hline \multicolumn{2}{|l|}{ People under 18 * } \\
\hline 0 & $625(67.4)$ \\
\hline 1 & $201(21.7)$ \\
\hline 2 & $73(7.9)$ \\
\hline 3 & $8(0.9)$ \\
\hline 4 & $2(0.2)$ \\
\hline 5 & $1(0.4)$ \\
\hline \multicolumn{2}{|l|}{ Education level * } \\
\hline PhD or higher & $111(12.0)$ \\
\hline Masters & $131(14.1)$ \\
\hline Higher education & $496(53.5)$ \\
\hline Complete high school & $153(16.5)$ \\
\hline Incomplete high school & $7(0.8)$ \\
\hline Incomplete elementary school & $5(0.5)$ \\
\hline
\end{tabular}

* 17 (1.8\%) people did not respond;

** Median: 36 (interquartile range: 27-52).

Table 6 shows an association between pesticide use and the fact that the household includes children aged under 18 years ( $\mathrm{p}$-value $=0.0026$ ). We can observe that relatively more significant use of pesticides ( $43.4 \%$ vs. $38.5 \%)$ is found when there are children aged under 18.

\section{Chemical group of products reported in household use}

Table 7 shows that the most frequent chemical group was pyrethrin and pyrethroid (55.8\%). When excluding the group of repellents, this percentage rises to $81.6 \%$. 
Table 2

Frequency of use of household pesticides in different studies in the previous year.

\begin{tabular}{lcc}
\hline Study & $\%$ & Local \\
\hline Bass et al. 23 * & 100 & 107 households in the state of Arizona (United States) \\
Grey 19 & 93 & 147 households in the city of Bristol (United Kingdom) \\
Diel et al. 16 & 89 & 2,039 households in the city of Pelotas (Rio Grande do Sul State/Brazil) \\
Current study & 87 & 927 households in the municipalities of Niterói, Rio de Janeiro and São Gonçalo (Rio de Janeiro State/Brazil) \\
Oliveira et al. 20 & 85 & 700 households in the city of Pico (Piauí State/Brazil) \\
Savage et al. 38 & 84 & 8,200 households in 25 counties in the United States \\
Whitmore et al. 22 & 82 & 2,078 households in 58 counties in the United States \\
\hline
\end{tabular}

* Evaluated time: 6 months.

Table 3

Frequency of responses by zone, region, and district of municipalities in Rio de Janeiro and Niterói, Rio de Janeiro State, Brazil.

\begin{tabular}{lc}
\hline & Frequency (\%) \\
\hline Rio de Janeiro & \\
Central Zone (Historic Center and Port Area) & $11(2.7)$ \\
North Zone (Greater Méier) & $32(7.9)$ \\
North Zone (Greater Tijuca) & $63(15.5)$ \\
North Zone (Governador Island and Leopoldina Zone) & $26(6.4)$ \\
North Zone (Other locations) & $34(8.4)$ \\
West Zone (Barra da Tijuca and Jacarepaguá) & $82(20.1)$ \\
West Zone (Greater Bangu) & $14(3.4)$ \\
West Zone (Other locations) & $23(5.7)$ \\
Missing data & $7(1.7)$ \\
Niterói & \\
Pendotiba Region & $35(8.2)$ \\
Eastern Region & $2(0.5)$ \\
North region & $53(12.4)$ \\
Oceanic Region & $59(13.8)$ \\
Bay Beaches Region & $279(65.2)$ \\
\hline
\end{tabular}

Table 4

Percentage distribution of respondents in each municipality who reported using each category of pesticide.

\begin{tabular}{lcccc}
\hline Municipality & Plants (\%) & Mosquitoes (\%) & Pest (\%) & Domestic animals (\%) \\
\hline Niterói & 4.0 & 56.5 & 23.0 & 16.5 \\
Rio de Janeiro & 3.6 & 59.6 & 23.5 & 13.3 \\
São Gonçalo & 1.4 & 56.3 & 20.5 & 21.9 \\
\hline
\end{tabular}


Table 5

Percentage distribution of valid respondents in each location by category of pesticide.

\begin{tabular}{|c|c|c|c|c|}
\hline Location & Plants (\%) & Mosquitoes (\%) & Pest (\%) & Domestic animals (\%) \\
\hline \multicolumn{5}{|l|}{ Niterói } \\
\hline Pendotiba Region & 3.8 & 53.2 & 19.0 & 24.1 \\
\hline Eastern Region & 0.0 & 50.0 & 50.0 & 0.0 \\
\hline North Zone & 2.4 & 50.4 & 24.0 & 23.2 \\
\hline Oceanic region & 3.1 & 55.5 & 21.1 & 20.3 \\
\hline Bay Beaches Region & 4.7 & 59.2 & 23.9 & 12.1 \\
\hline \multicolumn{5}{|l|}{ Rio de Janeiro } \\
\hline Central Zone (Historic Center and Port Area) & 0.0 & 68.8 & 25.0 & 6.3 \\
\hline North Zone (Other locations) & 3.1 & 63.1 & 20.0 & 13.8 \\
\hline North Zone (Greater Tijuca) & 0.8 & 66.9 & 21.1 & 11.3 \\
\hline North Zone (Governador Island and Leopoldina Zone) & 4.5 & 56.1 & 30.3 & 9.1 \\
\hline West Zone (Barra da Tijuca and Jacarepaguá) & 4.4 & 58.3 & 20.6 & 16.7 \\
\hline West Zone (Other locations) & 2.1 & 68.1 & 17.0 & 12.8 \\
\hline West Zone (Greater Bangu) & 4.5 & 68.2 & 18.2 & 9.1 \\
\hline South Zone & 6.0 & 54.3 & 27.2 & 12.5 \\
\hline North Zone (Greater Méier) & 1.6 & 51.6 & 29.0 & 17.7 \\
\hline São Gonçalo & 1.4 & 56.3 & 20.5 & 21.9 \\
\hline
\end{tabular}

Table 6

Association between pesticide use and housing children aged under 18 years.

\begin{tabular}{lccc}
\hline Housing children aged under $\mathbf{1 8}$ years & \multicolumn{2}{c}{ Use of pesticides } & p-value * \\
& Yes & No & \\
\hline Yes & 584 & 763 & 0.0026 \\
No & 1,162 & 1,858 & \\
\hline
\end{tabular}

* Chi-square test.

\section{Shelf search and online shelf search}

Pesticides were found in all surveyed markets and were available online on the website of all retailers that made buying online available. Most stores had more than 30 different types of products available for purchase. The website of three out of the four retailers offered more than 40 products for purchase. The variety of pesticides available for purchase was higher online than in the physical store in three of the four retailers that offered this type of acquisition. The most recurrent category for purchase was pesticides against pests (60.8\%), followed by mosquitoes (31\%) and domestic animals (8\%). 
Table 7

\begin{tabular}{lc} 
Chemical group of products reported in household use. \\
\hline Chemical group & Frequency \\
\hline Pyrethrin and pyrethroid & 774 \\
DEET & 306 \\
Icaridine & 115 \\
Fluralaner & 59 \\
Pyrazole & 34 \\
Oxadiazine & 16 \\
Neonicotinoid & 14 \\
IR 3535 & 11 \\
Spinosad & 10 \\
Neocotinoid & 10 \\
Inorganic ortho acids & 8 \\
Citronella & 8 \\
Amidinohydrazone & 6 \\
Carbamate & 6 \\
Organophosphate & 4 \\
Avermectin & 2 \\
Hidroxycoumarinic & 2 \\
Chlorpyrifos & 1 \\
Mothball & 1 \\
Organofluorinated & 1 \\
\hline &
\end{tabular}

\section{Discussion}

The results suggest a high exposure of the studied population to domestic pesticides. Most respondents used pesticides at home in the previous year (87\%), which is a result similar to several studies on the use of household pesticides summarized in Table 2. In total, 383 respondents (43.2\%) used products against pests. However, only $265(29.9 \%)$ reported having their households invaded by pests during that same period, which suggests that just over $30 \%$ of people used pesticides preventively. This pattern of use was also found in the study by Grey et al. 18 and is related to the level of individuals' risk perception of contact with pests, and their anticipated adverse impact resulting from that contact. The public tends to assess its own risk and, concerning the use of chemicals such as pesticides, the information it uses typically comes from media sources that, associated with intuition and cultural beliefs, instead of scientific bases, lead sometimes to disagree with the conclusions of academics and specialists 19,20 .

The study also attempted to collect detailed information about the types and brands of products used to identify the chemical substances used, understanding that knowing what the population is exposed to is fundamental to assess chronic health risks 21 . However, this information is not easily recalled. When asked in the online questionnaire to describe the specific products used, only $19.2 \%$ (195) answered about the product they used. The recall bias is a known limitation of retrospective studies. Studies such as by Whitmore et al. 22, Diel et al. 16 and Oliveira et al. 20 sought to reduce it by surveying the pesticides at the respondent's household at the time of the research, which was not possible in this study due to the high number of responses, broad physical area achieved by online disclosure, time, and financial issues.

Almost all respondents (93.5\%) reported storing pesticides inside the home, a concordant result, but much more relevant than those found in the studies by Bass et al. 23 (70\%) and Grey et al. 18 (50\%). In these two studies, the most common storage location was the kitchen, $45 \%$, and $42 \%$, respectively, 
while the service area $(60.3 \%)$ prevailed in our study, with the kitchen $(13.2 \%)$ as the second most frequent location. The most common place of use of the pesticide was the kitchen in the study by Bass et al. 23 , and the garden in the study by Grey et al. 18, while bedrooms (29.7\%) and the living room (22.1\%) prevailed in our study.

In all regions of the three municipalities studied, the most used category of products was that against mosquitoes. This result is similar to the study of Adgate et al. 24, who found that more than half of the active ingredients recorded and reported in the year before the study in Minnesota homes in the United States were also against mosquitoes.

The online survey revealed that, out of the 285 respondents who live with children aged under $18,259(90.8 \%)$ used some type of pesticide. Out of the 121 who used pesticides against pests, for example, 48 (39.7\%) had not been invaded by these animals in the previous year. These figures suggest an even higher frequency of exposure than the general population, and a preventive use pattern. These findings are concerning, especially regarding the potential exposure to pesticides under any circumstances, but even more so in households where children are more likely to be present. It is estimated that they spend more time indoors than other groups 25 , are more susceptible to toxic effects because they are less capable of metabolizing and excreting pesticides than adults 26 and significantly increase their probability of exposure when playing on surfaces treated with pesticides, such as a floor or lawn and then putting their hands in their mouths 27.

Concerning this group, relevant information regarding the use of household pesticides and damage to children's health is emphasized. Data from the National Toxicological and Pharmacological Information System (Sinitox) 28 showed that, in all years, from 2011 to 2016, the main circumstance of poisoning by household pesticides occurred due to an individual accident during use, with the main age group being 0 to 4 years ${ }^{29}$. Regarding clinical outcomes the meta-analysis by Chen et al. 13 showed that household exposure to insecticides and herbicides during childhood significantly increased the risk of leukemia $\left(\mathrm{OR}=1.47 ; 95 \% \mathrm{CI}: 1.26-1.72 ; \mathrm{I}^{2}=0 \%\right)$ and lymphoma $(\mathrm{OR}=1.43$; 95\%CI: 1.15-1.78; $\mathrm{I}^{2}=0 \%$. This association was not found with the use of pesticides outside the home.

The systematic review and meta-analysis of Van Maele-Fabry et al. 14 also showed a statistically significant association between residential exposure to pesticides and childhood leukemia $(\mathrm{SOR}=$ 1.57; 95\%CI: 1.27-1.95) in the combination of all studies without evidence of publication bias. Statistically significant risks were observed for all types of leukemia, specifically for exposure during pregnancy, indoor exposure, prenatal exposure to insecticides, and any age at diagnosis. Statistical significance was also achieved in the treatment with pesticides in pets, pest control professional use, and the use of insect repellents. The most significant risks were observed for acute myeloid leukemia in children aged two years and under, as well as for leukemia after prenatal exposure in a closed environment.

After combining all studies, another systematic review and meta-analysis by the same authors found a positive and significant association, between residential exposure to pesticides and brain tumors in children ( $\mathrm{mOR}=1.26$; 95\%CI: 1.13-1.40). No inconsistency was found between studies or publication bias. Statistical significance was also achieved for high-quality studies, all periods of exposure, internal exposure and, more particularly, during prenatal care, for all stratifications involving insecticides (except for external use), treatments on pets, treatment of fleas and ticks, in studies in the United States and Canada, studies in Europe (borderline), and data from studies that included children aged up to 10 years at diagnosis and aged up to 15 years 30 .

The authors conclude that, although causality cannot be established by the designs of the analyzed studies and the literature currently provides only studies of moderate and low quality - given the complexity of assessing the effects of chronic exposure to pesticides on health - the sum of evidence justifies the implementation of public health policies that limit the residential use of pesticides during pregnancy and childhood.

In this study, the chemical group of pyretrins and pyrethroids [55.8\% (774 citations)] was the most frequently used among those who reported which chemicals they used at home in the previous year. Excluding the group of repellents, this percentage rises to $81.6 \%$, making it comparable and consistent with the studies by Diel et al. 16 , which found products containing pyrethroids in $83 \%(1,340)$ of the households visited, and with the Oliveira et al. 20 , who found that products contained aerosols (almost all of which have pyrethroids as their main product) in $70.7 \%$ (495) of households at the time of the 
visit. Out of all products cataloged in shelf research in the physical market and online research, $86.1 \%$ of them contained pyrethroids as the leading chemical group.

Pyrethrins were developed as insecticides from extracts of the flower heads of Chrysanthemum cinerariaefolium. However, due to decomposing rapidly by light, synthetic analogues, a group of synthetic analogues of pyrethrins, were developed: the pyrethroids. All pyrethroids can exist as at least four stereoisomers, each with different biological activities and used widely as insecticides both in the home and commercially 15 . The main route of pyrethroid absorption is through the skin. Inhalation is much less significant but increases when pyrethroids are used in confined spaces. The main adverse effect of dermal exposure is paraesthesiae, presumably due to hyperactivity of cutaneous sensory nerve fibres. The face is the most affected region and the paraesthesiae are exacerbated by sensory stimulation such as heat, sunlight, scratching, sweating, or the application of water 31,32 . Pyrethroid ingestion gives rise within minutes to a sore throat, nausea, vomiting, and abdominal pain. There may be mouth ulceration, increased secretions and/or dysphagia. Systemic effects occur 4-48 hours after exposure. Dizziness, headache, and fatigue are common, and palpitations, chest tightness and blurred vision less frequent 31,33,34. Coma and convulsions are the principal life-threatening features 32 . Most patients recover within six days, although seven fatalities among 573 cases in one series and one among 48 cases in another were found.

Most studies have focused on occupational exposure to pesticides, however, chronic low exposure at home can have adverse effects similar to that due to the longer duration and frequency of exposure. Moreover, multiple levels of exposure to pesticides can generate synergy from the toxic effects of each of them, increasing the damage to individual health 35 . However, the long latency period between exposure and the onset of the disease 19 , and several factors could have contributed to the disease difficult studying the effect of long-term exposure to pesticides.

In an exploratory study, several methodological issues are identified when considering the use of pesticides at households. A selection bias occurred, and the sample was not representative of the Metropolitan Region of Rio de Janeiro because the responses were concentrated only in the municipalities of Niterói, Rio de Janeiro, and São Gonçalo, which means that the results are not generalizable to the population of the Metropolitan Region of Rio de Janeiro. The form of disclosure and response to the online questionnaire also selected respondents with higher education and living in regions with a high human development index in their municipalities. This may have influenced the pattern of pesticide use, as these regions have basic sanitation, regular garbage collection, and provision of vector and urban pest control services by the government, for example, nonexistent or inefficient in regions with more vulnerable populations, which were not considered by the online survey. On the other hand, the results ended up suggesting the pattern of pesticide use in the population of higher socioeconomic status in the municipalities specified in this study.

The literature shows that underreporting can occur in retrospective studies of self-reported pesticide use 18,36. However, this is unlikely to generate a systematic error since self-use reported use of pesticides is reliable ${ }^{37}$. Incorrect statements may also have occurred due to different interpretations of the word "pesticide", given its broad meaning. We tried to minimize this issue by asking specific questions about the use of pesticides in the online questionnaire.

This study aimed to produce a portrait of the pattern of use of domestic pesticides and the accessibility of these substances in physical and online stores in supermarkets in Rio de Janeiro. The created questionnaire had a good number of responses $(1,015)$ and the we conducted the first study on the topic in the state, however, limitations related to the questionnaire was found, for example, did not collect the information on the use and storage of the product by the consumer and limitation of the search technique through self-report, which commonly generates a memory bias and the selection bias of respondents due to the form of disclosure and response to the questionnaire, which was online. Thus, the results cannot be generalized for the entire Metropolitan Region, evidencing only the pattern of pesticide use of a specific group of the population in the municipalities of Niterói, Rio de Janeiro, and São Gonçalo. 


\section{Conclusion}

The survey showed that most respondents used pesticides at home in the previous year; the most used category was pesticides against mosquitoes; the most used chemical group of pesticides was pyrethroids and no variation was detected in the pattern of use in the different regions surveyed. Besides, pesticides are widely available for purchase in physical stores and online in supermarkets in Rio de Janeiro. The analysis of use against pests suggested a pattern of preventive use of pesticides by the general population in their homes, and even more frequent use in households where the presence of children is more likely, who are known to be more inclined to suffer effects when having contact with these toxic compounds. This result implies the need for further education on the dangers and the conscious use of pesticides, especially during pregnancy and when you have children at home, and guidance on other ways to minimize the action of mosquitoes, such as the use of mosquito net, for example, so the population can weigh the risks and benefits of an exposure whose effects and complications in the medium and long term are not yet apparent.

\section{Contributors}

L. L. S. Galdiano collaborated with the bibliographic review, data collection, construction of the database, and writing of the article. V. T. Baltar collaborated with the intellectual development of the project, methodology development, study orientation, and statistical analysis. S. Polidoro and V. Gallo collaborated with the intellectual development of the project and the development of the methodology.

\section{Conflict of interests}

The authors declare no conflict of interest.

\section{Additional informations}

ORCID: Leandro Lopes da Silva Galdiano (00000002-5561-8647); Valéria Troncoso Baltar (00000002-8152-8565); Silvia Polidoro (0000-00032968-0575); Valentina Gallo (0000-0002-12688629).

\section{References}

1. World Health Organization. Pesticides. https://www.who.int/topics/pesticides/en/ (accessed on 08/Jul/2020).

2. Arya N. Pesticides and human health: why public health officials should support a ban on non-essential residential use. Can J Public Health 2005; 96:89-92.

3. Lewis RG, Fortune CR, Blanchard FT, Camann DE. Movement and deposition of two organophosphorus pesticides within a residence after interior and exterior applications. J Air Waste Manage Assoc 2001; 51:339-51.

4. Curwin B, Sanderson W, Reynolds S, Hein M, Alavanja M. Pesticide use and practices in an Iowa farm family pesticide exposure study. J Agric Saf Health 2002; 8:423-33.

5. Kim KH, Kabir E, Jahan SA. Exposure to pesticides and the associated human health effects. Sci Total Environ 2017; 575:525-35.

6. Brasil VLM, Ramos Pinto MB, Bonan RF, Kowalski LP, da Cruz Perez DE. Pesticides as risk factors for head and neck cancer: a review. J Oral Pathol Med 2018; 47:641-51.

7. VoPham T, Bertrand KA, Hart JE, Laden F, Brooks MM, Yuan JM, et al. Pesticide exposure and liver cancer: a review. Cancer Causes Control 2017; 28:177-90.

8. Liang Z, Wang X, Xie B, Zhu Y, Wu J, Li S, et al. Pesticide exposure and risk of bladder cancer: a meta-analysis. Oncotarget 2016; 7:66959-69. 
9. Andreotti G, Koutros S, Hofmann JN, Sandler DP, Lubin JH, Lynch CF, et al. Glyphosate use and cancer incidence in the Agricultural Health Study. J Natl Cancer Inst 2018; 110:509-16.

10. Sheppard L, Shaffer RM. Re: Glyphosate use and cancer incidence in the Agricultural Health Study. J Natl Cancer Inst 2019; 111:214-5.

11. Samet JM. Expert review under attack: glyphosate, talc, and cancer. Am J Public Health 2019; 109:976-8.

12. Bolesi C, Merlo F. Pesticides: human health effects. Encyclopedia of Environmental Health 2019; 438-53.

13. Chen M, Chang CH, Tao L, Lu C. Residential exposure to pesticide during childhood and childhood cancers: a meta-analysis. Pediatrics 2015; 136:719-29.

14. Van Maele-Fabry G, Gamet-Payrastre L, Lison D. Household exposure to pesticides and risk of leukemia in children and adolescents: updated systematic review and meta-analysis. Int J Hyg Environ Health 2018; 222:49-67.

15. Bradberry SM, Cage SA, Proudfoot AT, Vale JA. Poisoning due to pyrethroids. Toxicol Rev 2005; 24:93-106.

16. Diel C, Facchini LA, Dall'Agnol MM. Domestic insecticides: pattern of use according to per capita income. Rev Saúde Pública 2013; 37:8390.

17. Associação Brasileira das Indústrias de Produtos de Higiene, Limpeza e Saneantes de Uso Doméstico e de Uso Profissional. ABIPLA Yearbook 40 years - 2016 Edition. São Paulo: Associação Brasileira das Indústrias de Produtos de Higiene, Limpeza e Saneantes de Uso Doméstico e de Uso Profissional; 2016.

18. Grey CN, Nieuwenhuijsen MJ, Golding J; LSPAC Team. Use and storage of domestic pesticides in the UK. Sci Total Environ 2006; 368:465-70.

19. Grey CNB. Household pesticides in the UK: use risk perception and policy implications. [Doctoral Dissertation]. London: University of London; 2003.

20. Oliveira LB, Nuner RMP, Santanda CM, Costa AR, Nunes NMF, Calou IA, et al. Profile of the population use of domestic insecticides to fight mosquitoes. Semina Ciênc Biol Saúde 2015; 36:79-92.

21. Pogoda JM, Preston-Martin S. Household pesticides and the risk of paediatric brain tumors. Environ Health Perspect 1997; 105:1214-20.

22. Whitmore RW, Kelly JE, Reading PL, Brandt E, Harris T. National home and garden pesticide use survey. In: Racke KD, Leslie AR, editors. Pesticides in urban enviroments. Washington DC: American Chemical Society; 1993. p. 1836.

23. Bass J, Ortega L, Rosales C, Petersen NJ, Philen RM. What's being used at home: a household pesticide survey. Rev Panam Salud Pública 2001; 91:138-44.

24. Adgate JL, Kukowski A, Stroebel C, Shubat PJ, Morrell S, Quackenboss JJ, et al. Pesticide storage and use patterns in Minnesota households with children. J Expo Anal Environ Epidemiol 2000; 10:159-67.
25. Weaver VM, Buckley TJ, Groopman JD. Approaches to environmental exposure assessment in children. Environ Health Perspect 1998; 106:827-32.

26. Faustman E, Silbernagel SM, Fenske RA, Burbacher TM, Ponce RA. Mechanisms underlying children's susceptibility to environmental toxicants. Environ Health Perspect 2000; 108:13-21.

27. Guha N, Ward MH, Gunier R, Colt JS, Lea CS, Buffler PA, Metayer C. Characterization of residential pesticide use and chemical formulations through self-report and household inventory: the Northern California Childhood Leukemia study. Environ Health Perspect 2013; 121:276-82.

28. Santana RAL. Sistema Nacional de Informações Tóxico-Farmacológicas: o desafio da padronização dos dados [Masters' Thesis]. Rio de Janeiro: Escola Nacional de Saúde Pública Sergio Arouca, Fundação Oswaldo Cruz; 2005.

29. Sistema Nacional de Informações Tóxico-Farmacológicas. Dados de intoxicação. https:// sinitox.icict.fiocruz.br/dados-de-agentes-toxi cos (accessed on 25/Jan/2020).

30. Van Maele-Fabry G, Gamet-Payrastre L, Lison D. Residential exposure to pesticides as risk factor for childhood and young adult brain tumors: a systematic review and meta-analysis. Environ Int 2017; 106:69-90.

31. He F, Wang S, Liu L, Chen S, Zhang Z, Sun J. Clinical manifestations and diagnosis of acute pyrethroid poisoning. Arch Toxicol 1989; 63:54-8.

32. Yang P-Y, Lin J-L, Hall AH, Tsao TCY, Chern $\mathrm{M}-\mathrm{S}$. Acute ingestion poisoning with insecticide formulations containing the pyrethroid permethrin, xylene, and surfactant: a review of 48 cases. J Toxicol Clin Toxicol 2002; 40:10713.

33. Garg P, Garg P. Mosquito coil (allethrin) poisoning in two brothers. Indian Pediatr 2004; 41:1177-8

34. Poulos L, Athanaselis S, Coutselinis A. Acute intoxication with cypermethrin (NRDC 149). J Toxicol Clin Toxicol 1982; 19:519-20.

35. Hull CL. When something is to be done: proof of environmental harm and the philosophical tradition. Environ Values 1999; 8:13-25.

36. Daniels JL, Olshan AF, Savitz DA. Pesticides and childhood cancers. Environ Health Perspect 1997; 105:1068-77.

37. Fortes C, Mastroeni S, Boffetta P, Salvatori V, Melo N, Bolli S, et al. Reliability of self-reported household pesticide use. Eur J Cancer Prev 2009; 18:404-6.

38. Savage EP, Keefe TJ, Wheeler HW, Mounce L, Helwic L, Applehans F, et al. Household pesticide usage in the United States. Arch Environ Health $1981 ; 36: 304-9$. 


\section{Resumo}

O estudo teve como objetivos estimar a exposição domiciliar a pesticidas em adultos na Região $\mathrm{Me-}$ tropolitana do Rio de Janeiro, Brasil, e verificar a acessibilidade a esses produtos no varejo local e nas vendas eletrônicas. Os dados foram coletados através de um questionário online (1.015 respostas) e uma pesquisa de varejo em lojas físicas e online. Entre as respostas analisadas, 87,5\% relataram o uso de pesticidas no último ano, a maioria contra mosquitos $(64,7 \%)$. O método de aplicação mais comum foi spray de aerossol $(38,1 \%)$, e os locais de uso mais frequente foram quarto de dormir (29,7\%) e sala de estar (22,1\%). Cerca de 30\% dos respondentes relataram a invasão de pragas, sendo os mais comuns: formigas $(79,1 \%)$ e baratas (40,4\%). Os locais de armazenamento mais comuns foram a área de serviço $(71,6 \%)$ e a cozinha (17,5\%). Aproximadamente 91\% dos que conviviam com crianças abaixo de 18 anos usavam pesticidas. Prevaleceu o uso do grupo químico dos piretróides (81,6\%), e 90,8\% dos produtos citados pertenciam à classe II [55,7\% (altamente tóxicos)] ou classe III [35, 1\% (toxicidade média)]. A quantidade mais significativa de produtos adquiridos pertencia à categoria das pragas, seguida pelos mosquitos. Havia maior disponibilidade de produtos via vendas online, comparado com lojas físicas. A exposição da população a pesticidas dentro de casa é um problema de saúde pública e confirma a necessidade de estudos para avaliar melhor os riscos e consequências da exposição crônica a doses baixas dessas substâncias. É essencial informar a população sobre as incertezas e potenciais riscos do uso indiscriminado para que possa escolher usar ou não pesticidas em suas residências.

Praguicidas; Habitação; Questionário; Acesso à Internet

\section{Resumen}

El objetivo de este estudio fue estimar la exposición a pesticidas en el hogar con personas adultas en la Región Metropolitana de Río de Janeiro, Brasil, y verificar la accesibilidad de estos productos en comercios locales y online. Los datos se recogieron a través de un cuestionario en línea (1.015 respuestas) y un trabajo de campo en tiendas físicas y en linea. Entre las respuestas analizadas, 87,5\% usaron pesticidas el año anterior, la mayor parte contra mosquitos (64,7\%). El método más común de aplicación fue aerosoles (38,1\%), y los lugares más frecuentes de uso fueron las habitaciones (29,7\%) y salas de estar $(22,1 \%)$. Cerca de un $30 \%$ de los encuestados informaron de la invasión de plagas, y las más comunes fueron hormigas $(79,1 \%) y$ cucarachas (40,4\%). Los lugares más comunes de almacenamiento fueron las áreas de servicios (zona para lavar y tender ropa) (71,6\%) y la cocina (17,5\%). Aproximadamente un 91\% de quienes vivían con niños menores de 18 usaron pesticidas. Prevaleció el uso del grupo químico de piretroides (81,6\%), y un 90,8\% de los productos usados informados son de clase II [55,7\% (altamente tóxicos)] o clase III [35,1\% (medio tóxicos)]. La cantidad más significativa de productos adquiridos fue en la categoría plaga, seguida por mosquitos. Había más variedad de productos disponibles en línea que en tiendas físicas. La alta exposición de la población a los pesticidas en el hogar es un asunto de salud pública y confirma la necesidad de estudios que evalúen mejor los riesgos y consecuencias tanto de una exposición crónica, como a dosis bajas de estas sustancias. Es esencial informar a la población sobre las incertidumbres y riesgos potenciales del uso indiscriminado, para que puedan elegir si usan o no pesticidas en sus hogares.

Plaguicidas; Vivienda; Cuestionario; Acceso a Internet
Submitted on 05/May/2020

Final version resubmitted on $20 / \mathrm{Sep} / 2020$

Approved on 19/Oct/2020 